\title{
Learning study: helping teachers to use theory, develop professionally, and produce new knowledge to be shared
}

\author{
Ming Fai Pang $\cdot$ Lo Mun Ling
}

Received: 11 August 2010/Accepted: 26 September 2011/Published online: 9 October 2011

(C) The Author(s) 2011. This article is published with open access at Springerlink.com

\begin{abstract}
The lesson study approach is a systematic process for producing professional knowledge about teaching by teachers, and has spread rapidly and extensively in the United States. The learning study approach is essentially a kind of lesson study with an explicit learning theory-the variation theory of learning. In this paper, we argue that having an explicit learning theory adds value to lesson study, as the variation theory of learning serves as a source of guiding principles for the teachers when they engage in pedagogical design, lesson analysis and evaluation. Through the use of two Hong Kong learning study cases, one from each of the two major ways of conducting learning study, we demonstrate the power of variation theory in explaining and predicting the relationship between what has taken place in the classroom and what the learners learn, and subsequently identifying ways to improve student learning through promoting teacher professional learning in a learning study setting.
\end{abstract}

Keywords Learning study · Variation theory of learning · Phenomenography · Lesson study $\cdot$ Teacher professional learning

\section{Introduction}

The stereotypical view that Asian classrooms are characterized by large class sizes, wholeclass teaching, teacher domination, and reliance on a transmission teaching approach, none of which are conducive to quality learning, has led to a paradox (Watkins and Biggs 1996) as international comparisons of student achievements in science and mathematics [e.g. Trends in International Mathematics and Science Study (TIMSS) and the Programme for International Student Assessment (PISA)] have consistently shown that Asian students perform better than most of their Western counterparts. To resolve this paradox, a number

M. F. Pang (ه)

Faculty of Education, The University of Hong Kong, Hong Kong SAR, China

e-mail: pangmf@hku.hk

L. M. Ling

Hong Kong Institute of Education, Hong Kong SAR, China 
of scholars have conducted studies that focused on what actually took place in classrooms in China and Japan. Contrary to popular belief, they found that many Chinese and Japanese teachers were more successful at helping students to develop deep subject matter learning and higher order thinking skills than their Western counterparts. This was attributed to the fact that Chinese and Japanese teachers focused on students' conceptual understanding in their classroom teaching and paid great attention to lesson planning (e.g. Ma 1999; Rohlen and LeTendre 1995; Stigler and Hiebert 1999; Yoshida 1999). Stigler and Hiebert (1999) further argue that the superiority of Japanese students in international tests can be credited to a particular teacher professional development model: the 'lesson study' approach in which Japanese teachers constantly engage with one another to develop their pedagogical knowledge and competence. As the teacher plays a key role in shaping student learning (Darling-Hammond 2000; Pong and Morris 2002; Fishman and Davis 2006), the Japanese lesson study is seen to be a professional development model that leads to better student learning. If this is indeed the case, then engaging teachers in lesson study will help teachers to achieve the goals of educational reforms.

In the Japanese lesson study approach, teachers plan lessons and evaluate classroom practices carefully and collaboratively for the purpose of improving their teaching and thus student learning (e.g., Lewis 2002). According to Lewis et al. (2006), lesson study 'encompasses a large family of instructional improvement strategies, the shared feature of which is observation of live classroom lessons by a group of teachers who collect data on teaching and learning, and collaboratively analyze it' (p. 3). Observed lessons are called 'research lessons'. According to Yoshida (1999), the lesson study cycle comprises the following steps:

(1) Choosing a topic: The topic could be a general problem, e.g. how to foster students' interest in learning, or it could have a more specific focus, e.g. to improve students' understanding of how to solve quadratic equations;

(2) Planning a lesson: Teachers draw upon relevant teaching resources and their own teaching experience to plan the lesson collaboratively;

(3) Teaching the lesson: One of the teachers is chosen to carry out the lesson plan and is observed by other teachers in the group, who note down the strengths and weaknesses of the lesson and areas for improvement;

(4) Evaluating the lesson and reflecting on its effect: The group holds a post-lesson debriefing meeting to evaluate the lesson itself, particularly its effectiveness and possible further improvement;

(5) Revising the lesson: The lesson may be revised based on the outcomes of the evaluation meeting;

(6) Teaching the revised lesson: The revised lesson plan is carried out in another class by either the same teacher or another teacher in the group;

(7) Evaluating and reflecting: The revised lesson is evaluated again and the process goes on until the group is satisfied with the quality of the lesson design;

(8) Sharing the results: The whole lesson study is shared and disseminated to other teachers in the same school or other schools through a seminar or published materials.

Since 1999, the lesson study approach has spread rapidly and extensively in the United States and is regarded as a system for producing professional knowledge about teaching (e.g. Hiebert et al. 2002). According to Lewis (2005), lesson studies improve teachers' thinking and practice as a result of (1) improved knowledge of subject matter; (2) improved 
knowledge of instruction; (3) improved ability to observe students; (4) stronger collegial networks; (5) stronger connection of daily practice to long-term goals; (6) stronger motivation and sense of efficacy; and (7) improved quality of available lesson plans (p. 115). Puchner and Taylor (2006) also show that the implementation of the lesson study model has successfully stimulated the dynamics and promise of teacher change and teacher efficacy. This lends support to the view of Jenlink and Kinnucan-Welsch (2001): 'professional development is most meaningful to educators when they have responsibility in the design and implementation of their own professional development and when it is closely connected to their work in classrooms' (p. 706).

However, as Chokshi and Fernandez (2004) highlight, one of the challenges for lesson studies in the United States is that some novice lesson study groups lack the critical elements that allow the approach to work, such as the development of tasks that reveal student thinking and discussion protocols that maintain teachers' focus on student learning. We attribute this to the lack of a common, explicit conceptual framework from which the group may draw when planning, implementing and reviewing the research lesson. The emergence of the learning study model as a lesson study variant (cf. Marton 2001) has helped to fill this gap as it emphasizes the use of variation theory (e.g. Marton and Booth 1997; Marton and Morris 2002; Marton and Tsui 2004; Marton and Pang 2006) as an explicit theoretical basis. The critical difference between learning study and lesson study lies in the presence of a learning theory which underpins the ways in which the teachers plan, implement and review the research lessons. The learning study approach is essentially a kind of lesson study with an explicit learning theory-the variation theory of learning.

In this paper, we argue that having an explicit learning theory adds value to lesson study, as the variation theory of learning serves as a source of guiding principles for the teachers when they engage in pedagogical design, lesson analysis and evaluation. Through the use of two Hong Kong learning study cases, one from each of the two major ways of conducting learning study, we demonstrate the power of variation theory in explaining and predicting the relationship between what has taken place in the classroom and what the learners learn, and subsequently identifying ways to improve student learning through promoting teacher professional learning in a learning study setting.

\section{The variation theory}

The learning study approach is premised on variation theory (for a more detail account, see Marton and Booth 1997; Marton and Morris 2002; Marton and Tsui 2004; Marton and Pang 2006), a theory that provides a rather unique perspective on learning and teaching. According to variation theory, learning primarily involves a qualitative change in the way we experience something in the world around us.

Any object or phenomenon has a number of aspects, e.g. shape, size, functions. The way in which a person experiences a phenomenon can be defined in terms of the particular aspects of that phenomenon the person focuses on and discerns simultaneously. If two people experiencing the same phenomenon are focusing on and thus discerning simultaneously different aspects of it, they will exhibit two different ways of experiencing the same phenomenon. For example, the hand may be experienced as providing useful information for crime detection when the finger prints are being focused on, or it may be experienced as an ingeniously designed machine when one is focusing on its functional aspect, and discerns how the hinges, joints and muscles work together. In order for a person 
to experience a phenomenon in a particular way, certain aspects, we called critical aspects, must be discerned simultaneously. Learning is a result of a change in the critical aspects of the phenomenon being discerned. In other words, after learning has taken place, the learner is able to discern the critical aspects that he or she was unable to discern before and/or is capable of discerning the relationship among critical aspects in a more considered and sophisticated manner.

Variation theory posits that the necessary condition for discernment is "experienced variation' on the part of the learner (Pang and Marton 2007). To be able to discern a certain critical aspect of a phenomenon, the learner needs to experience variation in that particular aspect. As Marton and Pang (2006) have argued, the discernment of a particular aspect amounts to experiencing a difference in the value of the aspect. For example, in order to discern the aspect 'colour', one must have experienced at least two different colours. If, hypothetically, there is only one colour in this world, the concept colour will not be discerned. Another example, is 'gender'. One would not be able to discern the concept of 'gender' if there were only men and no women in the world. In which case, there is no need to differentiate between male and female, and the concept gender will not be meaningful. Discernment is thus a function of experienced variation (male and female) in that particular aspect (gender in this case). According to Bowden and Marton (1998), when a particular aspect varies whilst all other aspects of the phenomenon are kept invariant, the learner will experience variation in the varying aspect and will discern that aspect. For example, when a child is shown three balls of the same size, shape, and material, but each of a different color: red, green and yellow, then it is very likely that the child's attention will be drawn to the color of the balls because it is the only aspect that varies.

\section{The conceptual framework of the learning study approach}

Two elements are pertinent in the learning study approach:

1. Keeping a sharp focus on the object of learning, this means identifying what is worthwhile for the students to learn, and identify the critical aspects that the students must discern in order to understand the object of learning in the intended way. An object of learning is a capability that the teachers considered worthwhile for the students to develop during the research lesson(s). Objects of learning have two aspects, direct or indirect. The former is defined in terms of content such as the rate of reaction in chemistry or demand and supply in economics, whereas the latter refers to the kind of capability that students can develop through learning the content, such as the ability to determine the rate of reaction for a certain chemical reaction through experimentation or being able to account for the change in the market price of a particular commodity according to simultaneous changes in demand and supply.

2. Applying the variation theory in every step of the process.

To help teachers to be mindful of the various aspects of the variation theory, three types of variation are spelt out and teachers who participate in learning studies are expected to draw upon these three types of variation in planning the lesson (see, for example, Lo et al. 2006).

V1 Variation in students' ways of seeing the object of learning.

When planning the lesson, teachers should make use of variation in students' experience or understanding of the object of learning. Phenomenographic studies have shown that 
students experience or understand a phenomenon in a limited number of qualitatively different ways. Teachers should nurture in themselves a capacity to understand the different ways in which students conceptualize what they are expected to learn and be sensitized to these individual differences. Instead of seeing these individual differences as problems or obstacles, teachers can regard them as a resource that can be harnessed to improve student learning. According to Stigler and Hiebert (1999), Japanese teachers believe that if there is great diversity in students' abilities and ways of thinking, it is more likely that students will create a diverse range of ideas and methods that teachers can make use of to enhance learning for the whole class. As Lo et al. (2002) argue in their discussion of the Catering for Individual Differences (Building on Variation) Project,

if pedagogy is to cater for individual needs, it must begin from a carefully defined object of teaching and learning. Equally crucial is a deep and thorough understanding of the different ways by which students come to acquire the capability targeted. It is through such an analysis that we can begin to accommodate the differences among them (p. 4).

\section{V2 Variation in teachers' ways of seeing and dealing with the object of learning.}

Through their daily professional practice and past experience, teachers may have developed a working knowledge of how to handle the object of learning in question, and this may vary from teacher to teacher. This knowledge may be in the form of tacit and unnoticed knowledge deemed useful in the course of designing the instructional approach. The sharing of this knowledge among teachers in the course of a learning study is seen as an extremely valuable input for determining the intended object of learning.

V3 Using variation as a guiding principle of pedagogical design.

Having gathered information from V1 and V2, teachers should be able to identify the critical aspects of the object of learning. To help learners appropriate a particular object of learning and experience the phenomenon in a new light, teachers participating in the learning study would then design a certain pattern of variation (which aspects to vary and which aspects to keep invariant) in a conscious and systematic way to enable students to discern the critical aspects of the object of learning and thus foster learning.

\section{The learning study approach}

This approach to teacher professional development involves a group of teachers who teach the same subject at the same level examining their own practices either with or without the support of researchers from higher education institutes. The steps involved are typical of an action research process: identify the problem, develop hypotheses, plan an action, try it out, evaluate its effect, and in most cases where it is possible, change the action plan and try again. What is distinctive about the learning study approach is that the main research problem is always 'How can the object of learning ' $\mathrm{X}$ ' be taught so that students can see ' $\mathrm{X}$ ' in the way intended?' ' $\mathrm{X}$ ' is chosen by all teachers through negotiation, on the basis that it is considered worthwhile to be learned by the students, it is central to the curriculum, and usually it is a topic that consistently presents difficulties for the students. During this process, both teachers and their students learn by gaining a deeper understanding of ' $\mathrm{X}$ ' and teachers develop pedagogical content knowledge about how best to deal with ' $\mathrm{X}$ ' in the lesson. 
Each learning study focuses on certain 'pedagogical units'. We define a pedagogical unit as a unit of teaching and learning in which a particular object of learning $-\mathrm{X}-\mathrm{can}$ be clearly defined and dealt with. Depending on the resources and time available, the pedagogical unit may be a topic of study in the curriculum, e.g. fractions in mathematics. The time required to deal with it could vary from a few weeks to a few lessons. The learning study could also focus on a particular critical aspect of a broader object of learning that may just fit into a single lesson, e.g. when the denominator is kept constant, the larger the numerator, the larger the fraction. Each pedagogical unit should enable the group to collect evidences that allow members to answer three important questions and learn from them:

1. What is the intended object of learning? In other words, what should students learn during the lesson? This involves selecting a worthwhile object of learning and studying it very carefully to determine its critical aspects, uncovering learning difficulties students are likely to encounter through interviewing students, administering a diagnostic pre-test to them, and by drawing on the literature or the teachers' past experience, and finally planning the lesson using variation theory (before they start participating in learning studies, teachers normally attend a course lasting no less than $12 \mathrm{~h}$ on the learning study approach and variation theory). The teaching arrangements and resources chosen, such as whether to use a whole-class teaching approach or group work, are subordinate to the pattern of variation and invariance designed by the teachers.

2. What is the enacted object of learning? This means establishing what actually happens in the lesson and involves observing the lesson very carefully, sometimes by taking a video recording for subsequent analysis.

3. What is the lived object of learning? This is related to what students have actually learned as a result of the lesson, which is usually determined by interviewing students after the lesson and comparing their pre- and post-test results. Delayed achievement tests and interviews are sometimes used to evaluate longer-term learning outcomes. Teachers should be mindful of students' ways of seeing during the lesson as well, and the variation theory states that variation must be experienced by the students in order for discernment to take place. Therefore, opportunities should be available during the lesson for the students to participate actively and to explain their ways of understanding the object of learning.

We believe that the answers to these questions will help teachers to understand the relationship between teaching and learning so that the knowledge gained can be fed back into teaching and generalized as professional knowledge. This process helps teachers to learn and is in line with well-known principles that support professional growth among teachers and are cited in the extant literature: teachers are engaged in activities related to classroom practice and such activities are aimed at improving student learning of particular content (Cohen and Ball 1999; Nuthall 2004; Stigler and Hiebert 1999); such activities are pursued over an extended period so there is sufficient immersion for teachers to have time to reflect and examine their practices and access to the results of their effort, thus encouraging continuing participation (Garet et al. 2001; Putnam and Borko 2000; Richardson and Anders 1994); teachers play a distinctive and important role (Putnam and Borko 2000; Fishman and Davis 2006).

Although the procedures and methods employed to carry out a learning study may vary, the underlying principles remain the same. One of the purposes of a learning study is to generate data that enable us to establish the relationship between teaching and learning. This can be done through a variety of methods. For example, one method is to have 
experimental and comparison groups along the lines of quasi-experimental studies. Another method is to conduct the research lessons in cycles. In this method, the group comes together to discuss ways to improve the lesson after each cycle. While the lesson plan remains largely the same in the second cycle, certain elements are introduced with the aim of improving the lesson. The differences in teaching enactment between cycles are then carefully analyzed and compared with student learning outcomes. The two examples of learning studies given in the following section capture the essence of what we mean.

The two learning study cases, one from each of the two major methods employed, are used to illustrate how learning study enhances student learning through promoting teacher professional development. They also illustrate the power of variation theory to predict and explain student learning outcomes. These cases are chosen as they are good examples to show what a typical learning study in each of the method is like.

The first case shows how a learning study along the lines of quasi-experimental studies was developed and carried out, and what can be learnt from it. The second example is typical of learning studies conducted in action research cycles. The two cases also serve to illustrate the commonalities and differences between the two methods. Both served to test the variation theory and to generate knowledge about its application. In the first example, what was to be tested was targeted in the design in advance. In the second example, while the research lesson was designed with the best intention of applying variation theory in practice, the action research cycles enabled gaps between theory and practice to be discovered and addressed, thus generating deeper knowledge of the theory in practice.

\section{Two examples of learning studies}

An example of a learning study along the lines of quasi-experimental studies: a primary four mathematics learning study

The learning study described here was conducted in a Hong Kong primary school. Four mathematics teachers were involved in the study. Two of the teachers formed a learning study group in which they used variation theory to develop a joint lesson plan for their two classes of primary four students. The two teachers in the comparison group taught their classes in the usual way as in previous years and administered a pre-test and a post-test on their students.

In this study, the object of learning agreed upon was to develop students' ability to understand the notion of 'equal shares' within the broader mathematical topic of fractions. This object of learning was chosen because the teachers believed that although 'fractions' is often a difficult topic for students, it forms the foundation of proportional thinking and students use fractions and/or fraction-related concepts in everyday life.

A pre-test was designed to ascertain how the students experienced the notion of 'equal shares' and how well they had mastered the concept. This included both multiple choicetype questions, and a question that asked for an open-ended response to afford students an opportunity to elaborate on how they understood the concept. We focus on the open-ended question only because it is most revealing in terms of how the students understood fractions.

Question 4 (see Fig. 1) was the open-ended question. The students were asked to identify what portion of the circle was shaded and to explain their answer. The purpose of 
Fig. 1 The figure used in question 4

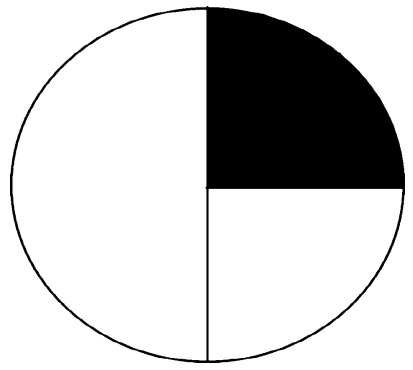

setting this question was to uncover variation in how the students understood or experienced the notion of 'equal shares' of a fraction.

Based on the students' answers in the pre-test, the teachers in the learning study group attempted to identify the critical aspects of the object of learning, i.e. the relationship between the denominator of a fraction and the meaning of a fraction. Taking this as the point of departure, they were guided by variation theory in planning the 1-h research lesson to bring out patterns of variation and invariance. The teachers followed the lesson plan closely as they taught the lesson.

To help the students discern the critical aspect of the denominator of a fraction, the teacher first introduced the meaning of $1 / 2$ and then varied the denominator by asking the students the meaning of $1 / 3$ and $1 / 4$ whilst keeping the numerator invariant. The intention was to help the students discern that the number of pieces into which the whole was cut changed according to the change in the denominator. Subsequently, to help the students generalize the notion of a fraction such as $1 / 2$ to other contexts, the teacher demonstrated the meaning of $1 / 2$ by cutting a pizza into two equal halves and demonstrated halves of other items such as oranges and cakes (Table 1).

Next, to help the students discern the critical aspects of 'equal shares' in fractions, the teacher cut a pizza into two unequal pieces and invited the students to contrast this with the previous scenario in which it was cut into two equal halves. This was intended to help the students discern that fractions carry the notion of 'equal shares'. To further generalize this notion, the teacher used other examples to demonstrate the splitting of two unequal pieces or two equal pieces from a whole. After the students had learned to discern the notion of 'equal shares', the teacher returned to the meanings of $1 / 3$ and $1 / 4$ presented earlier in the lesson, asking the students to examine whether the notion of 'equal shares' was present and the meaning of the fractions of $1 / 3$ and $1 / 4$ (Table 2).

Finally, the teacher used some other examples to vary both the number of pieces and whether they were divided into equal or unequal parts. This was intended to help the students to develop a deep understanding of the notion of 'equal shares' for a fraction. Table 3 captures the pattern of variation and invariance enacted in the lesson.

Table 1 First pattern of variation and invariance enacted in the learning study group

\begin{tabular}{lll}
\hline What is invariant & What varies & What is discerned \\
\hline The numerator (1) & The denominator & $\begin{array}{c}\text { The denominator denotes the number of equal } \\
\text { shares into which the whole is divided }\end{array}$ \\
\hline
\end{tabular}


Table 2 Second pattern of variation and invariance enacted in the learning study group

\begin{tabular}{lll}
\hline $\begin{array}{l}\text { What is invariant } \\
\begin{array}{l}\text { The object that } \\
\text { represents the } \\
\text { whole; the fraction }\end{array}\end{array}$ & $\begin{array}{l}\text { Splitting the whole into equal and } \\
\text { unequal parts according to the } \\
\text { fraction given }\end{array}$ & $\begin{array}{c}\text { The meaning of a fraction: the whole must } \\
\text { be split into equal parts according to the } \\
\text { denominator }\end{array}$ \\
\hline
\end{tabular}

Table 3 Third pattern of variation and invariance enacted in the learning study group

\begin{tabular}{lll}
\hline What is invariant & What varies & What is discerned \\
\hline The fraction & $\begin{array}{l}\text { Correct or incorrect fractions (the number } \\
\text { of pieces; equal share or not) }\end{array}$ & $\begin{array}{l}\text { A fraction indicates that the whole has been } \\
\text { divided into the number of equal parts } \\
\text { denoted by the denominator }\end{array}$ \\
\hline
\end{tabular}

Research lesson enacted in the comparison group

The teachers in the comparison group planned their lessons according to the curriculum outlines and the teaching resources of the school. Again, both teachers followed the lesson plan closely in teaching the lesson.

To start the lesson, the teacher counted 10 cubes into a bag. She then took out one cube and held it up, asking the students what fraction of the cubes was in her hand and what fraction of the cubes remained in the bag. The teacher then put the cube back in the bag and took out different numbers of cubes, asking the students the same question. The total number of cubes and the size of each cube were kept invariant whilst the number of cubes in her hand and in the bag varied in each round. The teacher's intention was to show the students that although the fractions were different in each instance, each and every cube was the same, represented 1/10 of the total of 10 cubes, and carried equal value. However, variation theory posits that what is discerned depends on the pattern of variation and invariance enacted in the lesson. As Table 4 shows, the lesson enacted actually led to a different learning outcome to that intended by the teacher. Furthermore, given that the size of the cubes did not vary, the idea that the cubes were of equal size may not have been discerned.

The teacher then invited the students to identify fractions in tenths such as $1 / 10,2 / 10$, and $3 / 10$ on a counting stick and did the same in fifths and halves along the same stick. The counting stick was kept invariant, but the counting unit or fraction varied. The teacher intended that this would help the students to understand the 'equal shares' attribute of a unit fraction by highlighting that $2 / 10$ is equal to two units of $1 / 10$ and that $3 / 10$ is equal to 3 units of $1 / 10$. However, variation theory predicts that as the teaching enactment resulted in the pattern of variation and invariance shown in Table 5, the concepts discerned are likely to have been different from those intended by the teacher.

Table 4 Pattern of variation and invariance enacted in the first activity

\begin{tabular}{lll}
\hline What is invariant & What varies & What is discerned \\
\hline $\begin{array}{l}\text { The whole (10 cubes); } \\
\text { size of each cube }\end{array}$ & $\begin{array}{c}\text { The numerator (number of cubes } \\
\text { taken out or left behind) }\end{array}$ & $\begin{array}{c}\text { The fraction depends on the numerator } \\
\text { (number of cubes taken out or left behind) }\end{array}$ \\
\hline
\end{tabular}


Table 5 Pattern of variation and invariance enacted in the second activity

\begin{tabular}{llc}
\hline What is invariant & What varies & What is discerned \\
\hline The counting stick & $\begin{array}{l}\text { Ways of counting: counting in tenths, } \\
\text { fifths, or halves } \\
\text { The representation, e.g. } 2 / 10 \text { or two } \\
\text { times } 1 / 10\end{array}$ & $\begin{array}{c}\text { It is possible to count using different } \\
\text { units or fractions } \\
\text { X/Y is the same as } \mathrm{X} \text { times } 1 / \mathrm{Y}\end{array}$ \\
\hline
\end{tabular}

Finally, the students were asked to work on an independent activity in which they were instructed to label $2 / 3,3 / 4,1 / 5,7 / 10$, and $9 / 12$ in the grids given. The total number of parts in each grid in the worksheet provided varied. The students had to use a separate grid for each of the fractions given and to decide which grid to use. The teacher intended that this would help the students to apply the notion of fractions to another context. Variation theory predicts that this activity in which every element varied should have brought about fusion, i.e. helped the students to bring together all the elements of the concepts they had mastered. However, it is doubtful that this activity was effective as the students might not have learnt the elements intended.

Thus, we see that the patterns of variation and invariance enacted in the two groups were different and are therefore likely to have helped the students to discern different things. Was this borne out by the student learning outcomes?

Student learning outcomes

Question 4 was an open-ended question that required a deep understanding of the notion of 'equal shares' of fractions. Because of the qualitative nature of question 4, students' answers were analyzed qualitatively according to the following categories:

A. The answer is incorrect and the explanation given appears to be unrelated to the answer given or does not make sense.

Example " $1 / 3$ because they were kept warm."

B. The answer given for deriving the fraction is related to the number of pieces rather than to the size of the pieces.

Example " $1 / 3$ because there are 3 boxes and one of them is shaded. So it is $1 / 3$."

C. Either an incorrect answer is given but the student notes a difference in the size of the pieces, or a correct answer is given but the explanation does not mention the size of the pieces involved.

Example "I think it is $1 / 3$, but I am not sure because one part is half."

D. A correct answer is given and the explanation is related to size, but appears to be incomplete.

Example "1/3 (if it is not equal) because there are three boxes and one is shaded. 1/4 (if you draw a line) because it is shared equally."

E. A correct answer is given and the student explains the size or idea of $1 / 2$ of $1 / 2$ being $1 / 4$ or adds a line to the diagram to explain his or her answer.

Example " $1 / 4$ of this shape is shaded. I know this because there are 3 pieces but they are not equal, so if you add a line, it becomes $1 / 4$."

As shown in Table 6, substantial differences were found in the answers given by the two groups to this open-ended question that required a deep understanding of the notion of 
Table 6 Comparison of pre-test and post-test results of learning study group and comparison group for question 4

\begin{tabular}{llllll}
\hline Category & \multicolumn{2}{l}{ Learning study group $(n=28)$} & & \multicolumn{2}{l}{ Comparison group $(n=31)$} \\
\cline { 2 - 3 } & Pre-test $(\%)$ & & & Pre-test $(\%)$ & Post-test $(\%)$ \\
\hline A & 14.29 & & & 12.90 & 3.23 \\
B & 21.43 & 14.29 & & 38.71 & 41.94 \\
C & 32.14 & 17.86 & & 12.90 & 12.90 \\
D & 7.14 & 10.71 & & 12.90 & 9.68 \\
E & 25.00 & 57.14 & & 22.58 & 29.03 \\
\hline
\end{tabular}

'equal shares'. The percentage of students in the learning study group (57.14\%) who managed to provide a correct answer and gave a proper explanation using the concept of 'equal shares' was much higher than that for the comparison group (29.03\%). Thus, the number of students in the learning study group who were able to appropriate the object of learning and demonstrate their understanding of it in the manner desired (Category E) was greater than that in the comparison group.

What had the teachers learned?

The teachers involved in the learning study revealed that their active participation had enhanced their sensitivity towards student learning and their own teaching. They appreciated the potential of variation theory in helping them to improve their teaching. This outcome is exemplified by comments made by one of the teachers involved:

By all accounts, this was simply a single lesson intervention that represented a first attempt at conducting a research lesson. There are things that could be refined, improved and maybe added to enhance the learning experience even further. Either way, I feel this will be a useful lesson to teach every year. It has inspired me to look at how the idea of variation can be further applied across the board throughout the various topics within mathematics as well as in other subjects. Naturally, things take time, but even if one highly structured lesson with systematic variation could be designed for each module, based on the results yielded in this experiment, the overall effect in terms of students' ability to perceive critical factors and differences will improve monumentally. As a result of this, I will be doing an even better job than I used to and hopefully equipping my fellow professionals with a piece of something that I myself am only beginning to understand more completely.

An example of a learning study conducted in action research cycles: a secondary four chemistry learning study

The case study described in this section is one of the 120 learning studies conducted in the Variation for the Improvement of Teaching and Learning (VITAL) project funded by the Hong Kong SAR Government. The research team consisted of three chemistry teachers in a secondary school (two of whom were involved in teaching the research lessons and the other being the head of the science department) and two researchers from the Hong Kong Institute of Education. The topic of 'factors affecting the rate of a chemical reaction' was chosen as this was a new topic for the teachers involved. The group deliberated on what 
would be a worthwhile object of learning for the research lesson. Some secondary four students were interviewed about their understanding of the topic to establish their prior knowledge, possible misconceptions, and difficulties they might encounter in learning this topic. Due to space limitations, we highlight some of the important features of this learning study that illustrate how learning study, and variation theory in particular, can contribute to professional development among teachers.

One of the interesting findings that helped to establish how the lesson could be planned to maximize student learning was that many students erroneously believed increasing the volume of a reactant increases the rate of the reaction. Therefore, in addition to other critical aspects (including the initial rate, the ability to interpret a rate curve, and the effect of concentration on the rate), the teachers decided that it was necessary to teach the 'effect of volume on the rate', i.e. that 'the volume of a reactant will NOT affect the rate of a chemical reaction when the concentration remains unchanged'. Due to the time constraint, it was decided that the research lesson would deal only with the effects of concentration and volume on the rate of a chemical reaction. A pre-test administered on the students in the two classes involved was carefully constructed to enable diagnosis of how well the students had mastered each of the critical aspects.

The research team decided to teach the lesson through an experiment in which diluted hydrochloric acid is added to solid calcium carbonate. The rate of the reaction can be determined by measuring the volume of carbon dioxide that evolves or by measuring the loss in the mass of the reactants as the carbon dioxide escapes. The reaction is summarized by the following chemical equation:

$$
\mathrm{CaCO}_{3}(\mathrm{~s})+2 \mathrm{HCl}(\mathrm{l}) \rightarrow \mathrm{CaCl}_{2}(\mathrm{aq})+\mathrm{CO}_{2}(\mathrm{~g})+\mathrm{H}_{2} \mathrm{O}(\mathrm{l})
$$

Two critical aspects were identified:

1. If the volume of the reactant remains unchanged, the concentration level will affect the rate of the chemical reaction;

2. If the concentration level of the reactant remains unchanged, the volume will not affect the rate of the chemical reaction.

The pattern of variation and invariance used in the research lesson is shown in Table 7.

To help the students to discern the critical aspects of the object of learning, the teacher carefully set different combinations of calcium carbonate and acid and assigned them to different groups of students. Table 8 shows the assignments given to three groups of students that would enable the first pattern of variation and invariance to be discerned. Table 9 shows the assignments given to another three groups that would enable the second pattern of variation and invariance to be discerned.

Each group of students was asked to draw the rate curve by plotting either the volume change or the mass change against time. The rate of the reaction for each assignment was given by the initial rate. The initial rates were used for comparison.

The teacher of the first research lesson cycle followed the lesson plan very closely. He was an experienced teacher with a good knowledge of chemistry and he explained the

Table 7 Intended pattern of variation and invariance

\begin{tabular}{llll}
\hline Mass of $\mathrm{CaCO}_{3}$ & Concentration of acid & Volume of acid & What is discerned \\
\hline $\begin{array}{lll}\text { Invariant } \\
\text { Invariant }\end{array}$ & Invariant & Varies & Volume has no effect on rate \\
& Varies & Invariant & Concentration affects the rate \\
\hline
\end{tabular}


Table 8 Practical work assignments for three groups of students

Table 9 Practical work assignments for another three groups of students

\begin{tabular}{llll}
\hline Group \# & $\begin{array}{l}\text { Mass of calcium } \\
\text { carbonate } \\
\text { (invariant) }(\mathrm{g})\end{array}$ & $\begin{array}{l}\text { Conc. of acid } \\
\text { (invariant) }(\mathrm{M})\end{array}$ & $\begin{array}{l}\text { Volume of acid } \\
\text { used (varied) } \\
\left(\mathrm{cm}^{3}\right)\end{array}$ \\
\hline 1 & 1 & 0.5 & 5 \\
2 & 1 & 0.5 & 10 \\
3 & 1 & 0.5 & 15 \\
\hline
\end{tabular}

\begin{tabular}{llll}
\hline Group \# & $\begin{array}{l}\text { Mass of calcium } \\
\text { carbonate } \\
\text { (invariant) }(\mathrm{g})\end{array}$ & $\begin{array}{l}\text { Conc. of acid } \\
\text { (varied) }(\mathrm{M})\end{array}$ & $\begin{array}{l}\text { Volume of acid } \\
\text { used (invariant) } \\
\left(\mathrm{cm}^{3}\right)\end{array}$ \\
\hline 4 & 1 & 0.5 & 5 \\
5 & 1 & 1 & 5 \\
6 & 1 & 1.5 & 5 \\
\hline
\end{tabular}

concepts very clearly to the students. The teacher used a strategy of 'pooling results' that is commonly employed by chemistry teachers in which each group of students works on a given concentration and volume and produces one rate curve for the reaction using their own data. The teacher then pooled the data of all the groups during the debriefing session to allow for conclusions to be drawn. Each group of students reproduced their rate curve on a transparency. The teacher then asked groups 1,2, and 3 to put their transparencies on the overhead projector so that the rate curves drawn by the different groups overlapped with each other. The gradients of the curves at the beginning of the reaction corresponded with the initial rates and the gradients of all the rate curves overlapped, showing that the initial rates were the same. The teacher then compared the results of groups 4, 5, and 6 in a similar way. The gradients did not overlap, showing that the initial rates were different.

Student learning outcomes

Although variation theory was used as a guiding principle in planning the lesson, it is always possible for a gap to exist between theory and practice and whether this is the case can be revealed only by carefully studying what happened in the lesson. We focus only on the second critical aspect of this learning study, i.e. the effect of volume on the rate, because this aspect was counter-intuitive to the students and it is often difficult to change a belief. The result of the following item answered the question: 'What have the students learned with respect to critical aspect 2?'

Q1. When $20 \mathrm{~cm}^{3}$ of $1 \mathrm{M} \mathrm{HCl}$ is added to $10 \mathrm{~g}$ of zinc (in excess), hydrogen is given out. How would the following actions affect the initial rate of the reaction?
A. Using $10 \mathrm{~cm}^{3}$ of $2 \mathrm{M} \mathrm{HCl}$ instead of $20 \mathrm{~cm}^{3}$ of $1 \mathrm{M} \mathrm{HCl}$
B. Using $20 \mathrm{~cm}^{3}$ of $3 \mathrm{M} \mathrm{HCl}$ instead of $20 \mathrm{~cm}^{3}$ of $1 \mathrm{M} \mathrm{HCl}$
C. Using $30 \mathrm{~cm}^{3}$ of $1 \mathrm{M} \mathrm{HCl}$ instead of $20 \mathrm{~cm}^{3}$ of $1 \mathrm{M} \mathrm{HCl}$
D. Adding water to the mixture
E. Using $\mathrm{HCl}$ of a higher concentration 
The students in class $4 \mathrm{~A}$ were able to answer parts $\mathrm{B}$ and $\mathrm{E}$ (which tested their understanding of the effect of concentration on the rate) quite well. However, they did badly in part $\mathrm{C}$ (which tested their understanding of the effect of volume on the rate) as the number of students who answered this item correctly in the post-test fell by $6 \%$ in comparison with the pre-test. Because the students were unable to understand how volume would affect the rate, they naturally did badly in parts A and D as they required an understanding of both critical aspects (concentration and volume) (Table 10).

To explain this outcome, we have to look into the lesson in greater detail (i.e. at what the enacted object of learning was) to see how variation theory helps to explain the result. The lesson was designed in a manner that basically reflects generally accepted science teaching strategies because the students were given plenty of opportunities for experimentation and were actively involved. What went wrong?

Variation theory proposes that for students to discern a critical aspect of the object of learning, they must experience variation in that aspect. Therefore, if this lesson was intended to help the students to discern the relationship between the initial rate and the volume of acid, they should have been able to experience variation in the initial rate and the volume simultaneously. Although the students were all actively engaged in the experiment and in plotting the rate curve, did they experience variation in the volume? Because each student worked in one group with a fixed volume and concentration, they did not experience the intended pattern of variation and invariance. The only time at which they were able to experience variation in the volume and the rate simultaneously was when the teacher pooled the results of the different groups during the debriefing session, especially when the teacher pointed out that the volumes varied while the rate remained unchanged. However, this took only a few seconds out of a lesson of about $120 \mathrm{~min}$. If the students were not paying attention at that point in time, they would have missed the most critical moment enabling them to experience simultaneous variation in volume and rate.

The second research lesson cycle

When the research team discovered this weakness in the first cycle, they made changes to the second cycle during which the research lesson was taught to class 4B. All the other planned activities remained the same, with one exception: the students were told that the purpose of the group work was to allow them to seek an answer to the question of whether the volume of a reactant affects the rate of the reaction. This meant that once they had finished the experiment, the students had to take their results and actively find the groups with the appropriate data that would help them to answer the question and make comparisons. The students were therefore provided with a better opportunity to experience the pattern of variation and invariance as intended, i.e. they had to figure out that they should compare their results with those of groups that had used acid with the same level of concentration but in a different volume.

Table 10 Percentage of students in class $4 \mathrm{~A}$ who answered

\begin{tabular}{lclc}
\hline $4 \mathrm{~A}$ & Parts A \& D correct & Parts B \& E correct & Part C correct \\
\hline Pre-test & $6 \%$ & $70 \%$ & $48 \%$ \\
$\begin{array}{c}\text { Post- } \\
\text { test }\end{array}$ & $24 \%(+18 \%)$ & $80 \%(+10 \%)$ & $42 \%(-6 \%)$ \\
\hline
\end{tabular}


Student learning outcomes

We found that while only $11 \%$ of the students in class $4 \mathrm{~B}$ answered the Part $\mathrm{C}$ items correctly in the pre-test, $80 \%$ of the students gave the correct answers in the post-test, representing an increase of $69 \%$. In comparison with class $4 \mathrm{~A}$, there was a marked improvement in the answers given for these items (Table 11).

What had the teachers learned?

All three teachers said that they had learned a lot. In particular, they learned that what really counts is not whether students are actively involved and are fully participating in activities, but whether they engage in activities that give them an opportunity to experience a pattern of variation and invariance that allows them to discern the intended object of learning. In the post-lesson interview, the class $4 \mathrm{~A}$ teacher commented:

I have taught for a number of years, and I have often thought that if I teach, students will learn. However, the test showed me that the students were not able to master what I had expected them to know. Through this research, I think that not only the students benefited, but we also learned a lot as teachers. When I first started, I thought that I was supporting the researchers from HKIEd and it had nothing to do with me. However, I later found that the whole team was doing the research and it was not possible for any party to do this research alone. It is a win-win situation.

The class $4 \mathrm{~B}$ teacher said:

I found that for students to learn, we must first establish the critical aspects, that is, what students know and what they do not know. This will help us in our teaching. I have learned so much through this research. I hope that I can use what I have learned in later lessons.

The teachers reached a consensus that this was not the end, but marked a beginning. They would use what they had learnt in subsequent lessons and in other science subjects and would spread the idea to other teachers in the school.

\section{Conclusion}

The collaborative nature of the learning study approach helps to break the culture of teacher isolation that is seen to be unfavorable for teacher development (Lortie 1975; Fullan 1991; Sarason 1999; Hargreaves et al. 2001). In this respect, it is very similar to the lesson study model. We are well aware that one thing all teacher professional development activities have in common is that they do not always lead to improved student learning; indeed, there are good reasons why some professional development activities are aimed at

Table 11 Comparison between pre- and post-test scores for the Part $\mathrm{C}$ items in the two classes

\begin{tabular}{lcc}
\hline $\begin{array}{l}\text { Percentage of students getting } \\
\text { the Part C items correct }\end{array}$ & 4A (\%) & 4B (\%) \\
\hline Pre-test & 48 & 11 \\
Post-test & 42 & 80 \\
Gain & -6 & +69 \\
\hline
\end{tabular}


something other than improving student learning. However, if the lesson study approach has become popular primarily as a result of its alleged success as a system for producing professional knowledge about teaching, then the capacity of this system to reveal student thinking and maintain teachers' focus on student learning is significant. In this respect, the learning study approach makes two main contributions over and above those of the lesson study model.

First, the central focus of learning studies remains squarely on student learning throughout, as their sole purpose is to help students to grasp an intended object of learning more effectively. Team members strive not only to identify an object of learning (whether a new curricular requirement or an old pedagogical problem), but also to address the object of learning by generating pedagogical content knowledge through cycles of evidence-based classroom action and, where necessary, consulting conceptual resources. One of the principal characteristics and salient features of the learning study model is that the pedagogical content knowledge generated is not simply the product of personal reflection, but also reflects the insights derived from disciplined efforts to improve teaching practice; it is knowledge that can be shared publicly and hence is open to scrutiny by others.

Second, the variation theory is used as a pedagogical tool. As we can see from the two learning studies, variation theory has both explanatory and predictive power. Teachers naturally use variations in their teaching; as an example, consider the comparison group in the first case study. Without being guided by a particular theory, the teacher made use of a particular pattern of variation and invariance that led to the learning of something unintended. Analysis of the pattern of variation enacted enabled us to predict that the students in the comparison group would not develop a good understanding of the concept of equal shares in fractions as their attention was not focused on the denominator and they did not have the opportunity to experience variation in equal and unequal shares. This was borne out by the student learning outcome. In the second case study, the poor student learning outcome in class $4 \mathrm{~A}$ with respect to the second critical aspect can be explained by variation theory. Guided by variation theory, the teacher of the second cycle was able to predict what changes should be made to foster better student learning and modified the lesson plan accordingly. This indeed resulted in an improved student learning outcome in class 4B.

We do not attempt to argue that research lessons developed through learning studies are perfect or extraordinary, or that learning studies are generally superior to the classroom teaching methods normally adopted by teachers. Rather, our key insight into teacher professional development is that the learning study approach made use of a learning theory that offers potential gains in the sense that it provides an additional theoretical component that may open up certain possible routes to improving student learning outcomes and, therefore, teacher learning outcomes (Pang and Marton 2003). Learning studies are designed to develop greater sensitivity among teachers to the students' point of view and to train teachers how to use variation theory as a tool that helps students to learn (Pang 2006). One could, of course, use theories other than variation theory, but one of the advantages of using a theory seems to be that teachers get better at using it every time they put it to the test. This two-way process - testing the theory through empirical studies and testing empirical studies against the theory-is necessary to close the gap between theory and practice. It is only by studying the enactment of teaching very carefully and taking an inquiry stance on practice (Cochran-Smith and Lytle 2001) that we can make sense of what actually happens in the lesson. The learning study approach provides teachers with a platform to engage in such inquiry and enables them to learn how to teach in a way that facilitates better student learning. 
Apart from the work in Hong Kong (e.g., Lo et al. 2005, 2006; Pang 2010; Pang and Marton 2003, 2005, 2007), learning studies have also been conducted in other places, for example in Sweden (e.g., Holmqvist 2006, 2011; Runesson 2005) and in UK (e.g., Davies and Dunnill 2008) in recent years. These studies have provided various insights into the relationship between teaching and learning for the teaching profession.

Acknowledgment This study was made possible thanks to grants from the University of Hong Kong.

Open Access This article is distributed under the terms of the Creative Commons Attribution Noncommercial License which permits any noncommercial use, distribution, and reproduction in any medium, provided the original author(s) and source are credited.

\section{References}

Bowden, J., \& Marton, F. (1998). The university of learning-beyond quality and competence in higher education. London: Kogan Page.

Chokshi, S., \& Fernandez, C. (2004). Challenges to importing Japanese lesson study: Concerns, misconceptions, and nuances. Phi Delta Kappan, 85(7), 520-525.

Cochran-Smith, M., \& Lytle, S. L. (2001). Beyond certainty: Taking an inquiry stance on practice. In A. Lieberman \& L. Miller (Eds.), Teachers caught in the action: Professional development that matters (pp. 45-60). New York: Teachers College Press.

Cohen, D. K., \& Ball, D. L. (1999). Instruction, capacity, and improvement. CPRE Research Report Series RR-43. Consortium for Policy Research in Education, University of Pennsylvania, Graduate School of Education.

Darling-Hammond, L. (2000). Teacher quality and student achievement. Educational Policy Analysis Archives, 8(1). http://epaa.asu.edu/epaa/v8n1.

Davies, P., \& Dunnill, R. (2008). 'Learning study' as a model of collaborative practice in initial teacher education. Journal of Education for Teaching, 34(1), 3-16.

Fishman, B. J., \& Davis, E. A. (2006). Teacher learning research and the learning sciences. In R. K. Sawyer (Ed.), The Cambridge handbook of the learning sciences (pp. 535-550). Cambridge: Cambridge University Press.

Fullan, M. G. (1991). The new meaning of educational change (2nd ed.). New York: Teachers College Press.

Garet, M. S., Porter, A. C., Desimone, L., Birman, B. F., \& Yoon, K. S. (2001). What makes professional development effective? Results from a national sample of teachers. American Educational Research Journal, 38(4), 915-945.

Hargreaves, A., Earl, L., Moore, S., \& Manning, S. (2001). Learning to change: Teaching beyond subjects and standards. San Francisco: Jossey Bass.

Hiebert, J., Gallimore, R., \& Stigler, J. W. (2002). A knowledge base for the teaching profession: What would it look like and how can we get one? Educational Researcher, 31(5), 3-15.

Holmqvist, M. (Ed.). (2006). Lärande $i$ skolan. Learning study som skolutvecklingsmodell. Lund: Studentlitteratur.

Holmqvist, M. (2011). Teachers' learning in a learning study. Instructional Science, 39(4), 497-511.

Jenlink, P., \& Kinnucan-Welsch, K. (2001). Case stories of facilitating professional development. Teaching and Teacher Education, 17, 705-724.

Lewis, C. (2002). Lesson study: A handbook of teacher-led instructional change. Philadelphia, PA: Research for Better School Inc.

Lewis, C. (2005). How do teachers learn during lesson study? In P. Wang-Iverson \& M. Yoshida (Eds.), Building our understanding of lesson study. Philadelphia, PA: Research for Better School Inc.

Lewis, C., Perry, R., \& Murata, A. (2006). How should research contribute to instructional improvement? A case of lesson study. Educational Researcher, 35(3), 3-14.

Lo, M. L., Chik, P. M. P., \& Pang, M. F. (2006). Patterns of variation in teaching the colour of light to Primary 3 students. Instructional Science, 34, 1-19.

Lo, M. L., Pong, W. Y., \& Chik, P. M. (Eds.). (2005). For each and everyone-catering for individual differences through learning studies. Hong Kong: Hong Kong University Press.

Lo, M. L., Pong, W. Y., Marton, F., Leung, A., Ko, P. Y., Ng, F. P., et al. (2002). Catering for individual differences building on variation: The first findings. Hong Kong: INSTEP, Faculty of Education, The University of Hong Kong. 
Lortie, D. C. (1975). Schoolteacher. Chicago: University of Chicago Press.

Ma, L. (1999). Knowing and teaching elementary mathematics. Mahwah, NJ: Lawrence Erlbaum Associates. Marton, F. (2001). Learning study. Unpublished manuscript.

Marton, F., \& Booth, S. (1997). Learning and awareness. Mahwah, NJ: Lawrence Erlbaum Associates.

Marton, F., \& Morris, P. (Eds.). (2002). What matters? Discovering critical conditions of classroom learning (pp. 9-18). Goteborg: Acta Universitatis Gothoburgensis.

Marton, F., \& Pang, M. F. (2006). On some necessary conditions of learning. The Journal of the Learning Sciences, 15, 193-220.

Marton, F., \& Tsui, A. B. M., with Chik, P. M., Ko, P. Y., Lo, M. L., Mok, I. A. C., Ng, F. P., Pang, M. F., Pong, W. Y., \& Runesson, U. (2004). Classroom discourse and the space of learning. Mahwah: Lawrence Erlbaum Associates.

Nuthall, G. (2004). Relating classroom teaching to student learning: A critical analysis of why research has failed to bridge the theory-practice gap. Harvard Educational Review, 74(3), 273-306.

Pang, M. F. (2006). The use of learning study to enhance teacher professional learning in Hong Kong. Teaching Education, 17, 27-42.

Pang, M. F. (2010). Boosting student financial literacy: Benefits of learning study. Instructional Science, 38(6), 659-677.

Pang, M. F., \& Marton, F. (2003). Beyond "lesson study" — comparing two ways of facilitating the grasp of economic concepts. Instructional Science, 31(3), 175-194.

Pang, M. F., \& Marton, F. (2005). Learning theory as teaching resource: Another example of radical enhancement of students' understanding of economic aspects of the world around them. Instructional Science, 33(2), 159-191.

Pang, M. F., \& Marton, F. (2007). The paradox of pedagogy: The relative contribution of teachers and learners to learning. Iskolakultura, 1(1), 1-29.

Pong, W. Y., \& Morris, P. (2002). Accounting for differences in achievement. In F. Marton \& P. Morris (Eds.), What matters? Discovering critical conditions of classroom learning (pp. 9-18). Goteborg: Acta Universitatis Gothoburgensis.

Puchner, L. D., \& Taylor, A. R. (2006). Lesson study, collaboration and teacher efficacy: Stories from two school-based math lesson study groups. Teaching and Teacher Education, 22, 922-934.

Putnam, R., \& Borko, H. (2000). What do new views of knowledge and thinking have to say about research on teacher learning? Educational Researcher, 29(1), 4-15.

Richardson, V., \& Anders, P. L. (1994). The study of teacher change. In V. Richardson (Ed.), Teacher change and the staff development process: A case in reading instruction (pp. 159-180). New York: Teachers College Press.

Rohlen, T. P., \& LeTendre, G. K. (Eds.). (1995). Teaching and learning in Japan. New York: Cambridge University Press.

Runesson, U. (2005). Beyond discourse and interaction. Variation: A critical aspect for teaching and learning mathematics. Cambridge Journal of Education, 35(1), 69-87.

Sarason, S. B. (1999). Teaching as a performing art. New York: Teachers College Press.

Stigler, J. W., \& Hiebert, J. (1999). The teaching gap: Best ideas from the world's teachers for improving education in the classroom. New York: The Free Press.

Watkins, D. A., \& Biggs, J. B. (Eds.). (1996). The Chinese learner: Cultural, psychological and contextual influences. Hong Kong: Comparative Education Research Centre, Faculty of Education, University of Hong Kong.

Yoshida, M. (1999). Lesson study [Jugyokenjyu] in elementary school mathematics in Japan—a case study. Paper presented at the annual meeting of the American Educational Research Association, Montreal, Canada. 